\section{WELCOMING LA DENTISTA!}

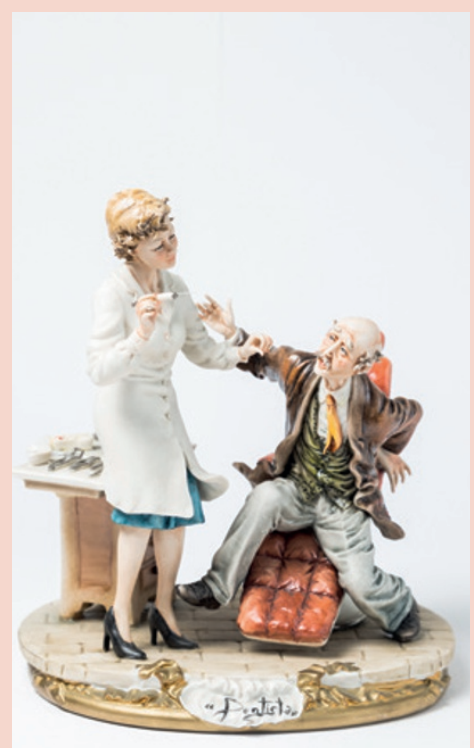

The museum has received a recent donation of dental figurines and instruments in memory of Trevor Malcolm Payne (1948-2010) from his family. The figurines were collected over a number of years whilst Trevor was on holiday and representing the BDA abroad. Of particular interest are the Italian Capodimonte porcelain figurines. First produced at its factory in Naples in 1743 , Capodimonte became famous for its moulded figurines and decorative flowers, cups and vases. The Capodimonte porcelain tradition flourished and continues to be highly collectible. The example shown, La Dentista, was made by artist Walter Scapinello.
FGDP(UK) SUPPORTS NICE DECISION ON GUIDANCE FOR PROPHYLAXIS AGAINST INFECTIVE ENDOCARDITIS

The Faculty of General Dental Practice UK (FGDP(UK)) welcomes the update to the NICE guidance on prophylaxis against infective endocarditis (IE) and supports its recommendation that no changes be made to the original guidance published in 2008. In a statement the Faculty noted the 'robustness of the process and methods used to carry out the review', and hoped that the advice will be accepted by all healthcare professionals and that patients at risk of infective endocarditis are advised of the importance of maintaining good oral health.

The FGDP(UK)'s guidelines Antimicrobial prescribing for general dental practitioners reflect the NICE guidance and with the increasing problem of antimicrobial resistance provide evidence-based guidance for prudent prescribing and antimicrobial stewardship.

This 2015 update was triggered by a recent study suggesting that the incidence of IE may have been affected by the 2008 guidance. As a precaution, NICE reviewed the evidence and found no need to change any of the existing guidance.

\section{HONOURS, AWARDS AND APPOINTMENTS}

\section{ALLAN THOM TO BE PRESIDENT OF WFO}

For the first time in the 20-year history of the World Federation of Orthodontists, a UK orthodontist has become its President. Allan Thom, a past-president of the British Orthodontic Society, took on the prestigious role on the last day of the 8th International Orthodontic Congress in London on 30 September.

Dr Thom has served as President Elect of the WFO for the last five years and is on the Executive Council. His role as President continues until 2020 when he will hand over to his successor at the culmination of the 9th International Orthodontic Congress in Japan.

Speaking for the first time as President of WFO, Dr Thom will emphasise the importance of the WFO in supporting colleagues in areas of the world plagued by civil unrest.

Dr Thom said: 'There must be strong support for our present fellows and elected representatives in these countries who are trying to maintain both a service and high standards to patients under challenging conditions.'

He pledged the WFO's commitment to help deserving young orthodontists attend future IOC meetings. 'A concept instigated at this IOC has facilitated 35 young orthodontists from less affluent countries who would not normally have been able to come to London to attend and learn from top international speakers. A life changing experience for them and something we would like to perpetuate.

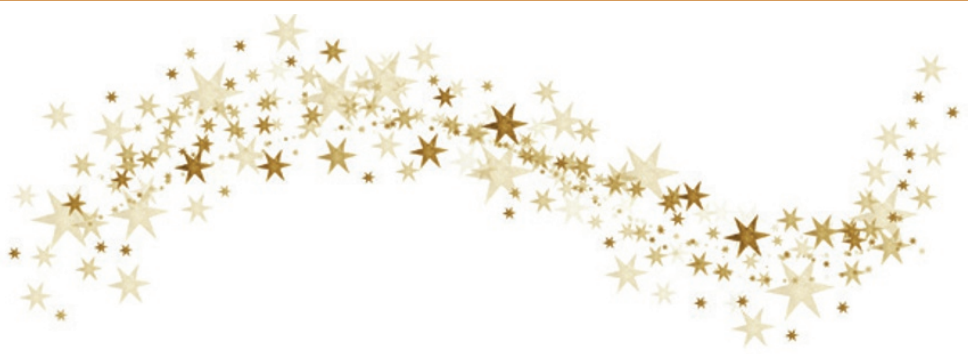

DR PATRICK HESCOT IS THE NEW FDI PRESIDENT

Dr Patrick Hescot is the new President of FDI World Dental Federation. He began his two-year mandate on 24 September, following an inauguration ceremony during the meeting of the FDI General Assembly, the Federation's governing body, in Bangkok.

Dr Patrick Hescot, a French national, has been involved in FDI work for over 20 years. He is a former President of the FDI European Regional Organisation (ER0), served on the FDI Council since 2007 and was designated President-Elect in 2013.

He is currently Chair of the FDI's Observatory and Strategy for Africa Task Teams. He has been an expert on oral health for the World Health Organisation (WHO) and Director of a WHO Collaborating Centre since 1998. He is also a former President of the French Union for Oral Health (Union Francaise de Santé Bucco-Dentaire - USFBD) and a former Secretary General of the French Dental Association (Association Dentaire Française - ADF).

Commenting on his inauguration, FDI President Hescot said: 'To take on the mandate of FDI President requires energy and commitment as well as a dedication to close collaboration with my friends and colleagues in national dental associations worldwide.

'Today, dentists are key socio-economic players with responsibilities for our patients' quality of life. Good oral health is an integral part of wellbeing and a fundamental right of all people. This is the message I will be communicating to governments, international institutions such as WHO and to the media during my term of office,' concluded the FDI President.

Dr Hescot takes over from Dr Tin Chun Wong from Hong Kong. 